\title{
ASSESSING THE IMPACT OF THE UNITED NATIONS WAR CRIMES COMMISSION ON THE PRINCIPLE OF COMPLEMENTARITY AND FAIR TRIAL STANDARDS
}

\begin{abstract}
This article looks at the work of the United Nations War Crimes Commission (UNWCC), and its influence on the development of international criminal law. It examines the role the UNWCC played in prosecuting war criminals, and notes the similarities between the UNWCC's mission and the current structure and role of the International Criminal Court, particularly its focus on the principle of complementarity. The article reviews fair trial standards at the time of the national trials, and provides that many of them are present in current international human rights instruments. Still, the author submits that many trial records are still inaccessible and, as a result, there is not enough evidence to fully analyze the Commission's efficiency in providing for a fair and impartial trial.
\end{abstract}

\section{INTRODUCTION}

The work of the United Nations War Crimes Commission (UNWCC or the Commission) has rarely been discussed in relation to the prosecution of war crimes during the Second World War. Recently released documents, however, have changed this and have subsequently shed light on the Commission's influence on the development of interna-

* Dr Mark S. Ellis is Executive Director of the International Bar Association (IBA). Dr Ellis served as Legal Advisor to the Independent International Commission on Kosovo and was appointed by the OSCE to advise on the creation of Serbia's War Crimes Tribunal. He was actively involved with the Iraqi High Tribunal and is a member of the Disciplinary Advisory Panel to the Defence Counsel for the ICTY and ICTR. He also acted as a legal advisor to the defence team of Nuon Chea at the Cambodian War Crimes Tribunal (ECCC). The author would like to acknowledge the exceptional work by Gillian Quinn in helping research and draft this article. The author also wishes to thank Dr Dan Plesch and Shanti Sattler for organising the UNWCC 70th Anniversary Conference at SOAS, University of London in September 2013. 
tional criminal law. ${ }^{1}$ In order to assist in the current effort to draw attention to the work of the Commission, this article discusses some of the early debates on both the principle of complementarity and the creation of an international court to try high-level war criminals. This article will also examine the provisions that afforded the accused the right to a fair trial. Although it is important to highlight the positive influence that the Commission had on the development of law, and the vital role that the Commission played in the prosecution of war criminals, it is also necessary to consider the trials themselves. Justice Richard Goldstone once said to me that the yardstick measure for an international court is not the number of convictions; it is whether the defendants received a fair trial. ${ }^{2}$ The same should hold true for the work of the UNWCC. Given that many of the UNWCC trial records are still inaccessible, further research will be needed to fully assess the efficiency of the Commission in ensuring a fair and impartial trial.

\section{UNWCC: CREATION AND FUNCTIONS}

The atrocities committed during the Second World War compelled the Allied nations to seek international prosecution for these crimes. In October 1941, Winston Churchill and Franklin D. Roosevelt condemned the acts which had been committed by Germany and threatened that there would be retribution for the actions of the German forces. ${ }^{3}$ Following these calls, the Inter-Allied Commission on the Punishment of War Crimes was established in January 1942, and the St. James Declaration was issued. ${ }^{4}$ Under the St. James

\footnotetext{
${ }^{1}$ In July 2013, more than 2,240 documents from the UNWCC's archive were made publically available in the International Criminal Court (ICC) Legal Tools Database. ICC Press Release, 'UN War Crimes Commission's archive is now available in the ICC Legal Tools Database' (2013) < http://www.icc-cpi.int/en_menus/icc/press $\% 20$ and $\%$ 20media/press\%20releases/Pages/pr925.aspx > accessed 11 December 2013 (UNWCC Documents).

${ }^{2}$ Comment from Justice Richard Goldstone to the author, Dr Mark Ellis, regarding the International Criminal Tribunal for the Former Yugoslavia (January 1996).

${ }^{3}$ The United Nations War Crimes Commission (UNWCC or the Commission) (ed.), History of the United Nations War Crimes Commission and the Development of Laws of War (His Majesty's Stationary Office, 1948) 87-88 (History of the UNWCC).

${ }^{4}$ The Inter-Allied Declaration on Punishment for War Crimes reprinted in Punishment for War Crimes: The Inter-Allied Declaration Signed at St James Palace, London 13 January 1942 and Relative Documents (His Majesty's Stationary Office, 1942) (St. James Declaration); History of the UNWCC, ibid, 89-92.
} 
Declaration, the signatories committed themselves to "the punishment, through the channel of organized justice, of those guilty of or responsible for these crimes, whether they have ordered them, perpetrated them, or participated in them". 5 The St. James Declaration established the UNWCC. However, it was the Moscow Declaration, signed in October 1943, which specified the scope of the Commission. The Moscow Declaration provided that:

Those German officers and men and members of the Nazi party who have been responsible for or have taken a consenting part in the above atrocities, massacres and executions will be sent back to the countries in which their abominable deeds were done in order that they may be judged and punished according to the laws of these liberated countries and of free governments which will be erected therein. ${ }^{6}$

The signatories of the Moscow Declaration declared that those who had committed crimes, which had "no particular geographical localisation", would be punished by a joint decision of the Allied governments. ${ }^{7}$

However, at the time of signature, there was no indication whether the joint action of the governments referred to judicial proceedings or simply a political declaration of guilt. ${ }^{8}$

More than a year after the St. James Declaration was signed; the UNWCC was established on 20 October 1943 by seventeen Allied nations. ${ }^{9}$ The Commission was tasked with the following:

${ }^{5}$ The St. James Declaration was signed by representatives of the Governments of Belgium, Czechoslovakia, France, Greece, Luxembourg, Norway, the Netherlands, Poland and Yugoslavia; History of the UNWCC (n 3) 89.

6 'Declaration of Four Nations on General Security' reprinted in 'Great BritainSoviet Union-United States Tripartite Conference in Moscow' (1944) 381 (Supp.) AJIL 3-8 (Moscow Declaration). See also UNWCC, Declarations by United Nations Governments and Leaders on the Subject of War Crimes, Doc. C.29 (14 June 1944).

${ }^{7}$ Moscow Declaration (n 6).

${ }^{8}$ UNWCC, The Problem of Major War Criminals, Doc. C.111 (16 May 1945) 1.

${ }^{9}$ The state parties to the UNWCC included; Australia, Belgium, Canada, China, Czechoslovakia, France, Greece, India, Luxembourg, the Netherlands, New Zealand, Norway, Poland, the United Kingdom, the United States, Yugoslavia and South Africa (however, South Africa took part in the creation of the UNWCC, but did not hold national trials or continue significant involvement); UNWCC, Progress Report adopted by the Commission on 19th September 1944, Doc. C.48(1) (19 September 1944) 1; Denmark later joined the UNWCC in July 1945; See D. Plesch and S. Sattler, 'Changing the Paradigm of International Criminal Law: Considering the Work of the United Nations War Crimes Commission of 1943-1948' (2013) 152 Intl Com L Rev. 203. 
(i) To collect, investigate ${ }^{10}$ and record evidence of war crimes, identifying where possible the individuals responsible.

(ii) To report to the Government concerned cases where the material available appeared to disclose a prima facie case.

(iii) To act as a Committee of Legal Experts charged with advising the Governments concerned upon matters of a technical nature, such as the sort of tribunals to be employed in the trial of war criminals, the law to be applied, the procedure to be adopted and the rules of evidence to be followed. ${ }^{11}$

The UNWCC, located in London, established three committees: Committee I (Facts and Evidence) examined the charges filed by the Allied nations; Committee II (Enforcement) was concerned with "the detection, apprehension, trial and punishment of suspected war criminals"; and Committee III (Legal Committee), which advised the Commission on legal matters. ${ }^{12}$ Following calls from the Chinese government, an investigative branch of the UNWCC, the Far Eastern and Pacific War Crimes Sub-Commission was also created in Chungking, China. ${ }^{13}$ The nations involved established National Offices for the purpose of preparing charges against alleged war criminals and "transmitting them with the relevant information and

${ }^{10}$ The investigating function of the UNWCC was envisaged in the Moscow Declaration; UNWCC, Annex $V$-Establishment of closer cooperation between the UNWCC and the National Offices, Doc. NOC.5 (2 June 1945) 1.

${ }^{11}$ History of the UNWCC (n 3) 3; United Nations Archives Predecessor Archives Group, United Nations War Crimes Commission 1943-1949, UN Doc. PAG-3/Rev. 1 (1987) i; UNWCC, Problems Facing the Commission, Doc. II/39 (6 May 1945) 1; History of the UNWCC (n 3) 3; UNWCC, Draft of a Note on the Legal Aspect of the work of the United Nations War Crimes Commission, Doc. A.32 (29 January 1947) 2; UNWCC, The Legal Status of the United Nations War Crimes Commission, Doc. Misc. No. 7 (7 Jan 1946) 1; 'Cablegram from the Secretary of State for Dominion Affairs, London to the Australian Prime Minister's Department, Canberra' War Criminals, Establishment of United Nations Commission, Australian War Crimes Commission, $(26$ November 1942) NAA MP742/1 336/1/1145 < http://recordsearch.naa.gov.au/Search NRetrieve/Interface/DetailsReports/ItemDetail.aspx? Barcode $=392411>$ accessed 11 December 2013.

12 United Nations War Crimes Commission 1943 -1949 (n 11) iii.

${ }^{13}$ History of the UNWCC (n 3) 129-130; UNWCC, Draft Letter to the Governments submitted by the Committee on the Establishment of a Far Eastern and Pacific Sub-Commission, Doc. C.25 (2 June 1944). See UNWCC, Final Report of the Far Eastern and Pacific Sub Commission of the United Nations War Crimes Commission, Doc. Misc. No. 109 (17 September 1947). 
material for the substantiation of the charges for examination by the Commission". ${ }^{14}$

According to a letter written by Sir Anthony Eden, British Foreign Secretary, the Commission was an "advisory body", which was responsible for the "classification of crimes" committed by Axis forces, and made legal recommendations in line with "Allied declarations" ${ }^{15}$ Although the UNWCC was tasked with the investigation of war crimes, the Commission had no executive power and no detective staff. The responsibility for apprehending suspected war criminals rested with the national or occupational authorities. ${ }^{16}$ The Allied Powers simply did not provide the UNWCC with sufficient resources, nor with any real authority to conduct its work. ${ }^{17}$ Unfortunately, the same deficiencies affected the National Offices, which also had inadequate staffing and which failed to exchange and coordinate information among themselves, or report all cases to the Commission. ${ }^{18}$ Professor Cherif Bassiouni notes that despite "high expectations", this "investigative body was subordinated to political considerations and ultimately relegated to a role far inferior to that which was expected by the Allies". 19

Although the UNWCC listed the charges, it was not empowered to make binding decisions on the Allied nations, and cases against "minor" war criminals did not require authorization by the Commission. ${ }^{20}$ After the National Offices submitted a case, the Com-

\footnotetext{
${ }^{14}$ Progress Report, Doc. C.48(1) (n 9) 1.
}

15 'Letter written on behalf of the Foreign Secretary, Mr Eden, on February 24th, 1944, to all Governments represented on the Commission' in UNWCC, Memorandum on the Present Position of the United Nations War Crimes Commission and the Work Already Done, and its Future Tasks - Presented by Mr B Ečer, Doc. C.76 (8 February 1945) 5-6; UNWCC, Article by Lord Wright in 'New York Times' of May 13th 1945: That Guilty Shall Not Escape, Doc. C.128 (21 June 1945) 4.

${ }^{16}$ Draft of a Note, Doc. A.32 (n 11) 11; History of the UNWCC (n 3$) 3$.

${ }^{17}$ M. C. Bassiouni, Introduction to International Criminal Law (Leiden, Martinus Nijhoff Publishers, 2nd edn, 2012) 550-551.

18 Problems Facing the Commission, Doc. II/39 (n 11) 1.

${ }^{19}$ Bassiouni (n 17) 550-551.

${ }^{20}$ Draft of a Note, Doc. A.32 (n 11) 3; Telegram from Lord Wright to H. E. Evatt (6 October 1945) cited in Telegram 316 (12 October 1945) CRS A2937 222 (as cited in D. Sissons, 'The Australian War Crimes Trials and Investigations (1942-1951)' (2006) Papers of David Sissons, National Library of Australia, MS 3092, Series 1.3, Folder 24); Cablegram sent by Oldham to External Affairs (12 October 1945) NAA A1066 H45/590/ $1<$ http://recordsearch.naa.gov.au/SearchNRetrieve/Interface/DetailsReports/Item Detail.aspx?Barcode $=187967>$ accessed 11 December 2013. 
mission would determine whether there was prima facie evidence that a war crime had been committed. If the answer was 'yes' then it would justify the apprehension and prosecution of the individual accused, or at least consider the persons as suspects or material witnesses. ${ }^{21}$ Once a prima facie case was established, the Commission added the accused's name to the 'Lists of War Criminals, Suspects and Witnesses', which were prepared and issued by Committee I. The national authorities would then proceed with criminal trials. ${ }^{22}$

As mentioned above, in the early stages of its creation, the Commission struggled to gain momentum due to the lack of resources and funding. Sir Cecil Hurst, the first Chairman of the UNWCC, even expressed doubt that the Commission could fulfill its mandate. ${ }^{23}$ In the first five months of its creation, the Commission had only received some 60 cases, most of which were considered as Class ' $\mathrm{C}$ ' cases (adjourned cases and cases whereby the accused was not identified) or were incomplete. ${ }^{24}$ The low number of cases received by the Commission was also attributed to the high standards required by Committee I before accepting charges.

Following criticisms from various representatives on the Commission, it was decided that all members of a military would be listed if it "appeared that crimes were committed on such a scale that it could be presumed that all members of the unit could be suspected of taking part". ${ }^{25}$ It was only after the Allied liberation of the occupied territories that the scale of the atrocities became clear, and the Allied nations could accordingly focus their attention on the punishment of war criminals. The Allied governments began to provide the Commission with more cases, and during its existence, the Commission received 36,810 cases from the National Offices. ${ }^{26}$ However, given that the UNWCC was mainly comprised of representatives from exile governments possessing only limited powers, the UNWCC had "little political influence and support". ${ }^{27}$ Consequently, support for the Commission dwindled and the focus of the Allied community shifted

\footnotetext{
${ }^{21}$ Draft of a Note, Doc. A.32 (n 11) 8, 11; Memorandum, Doc. C.76 (n 15) 5-6.

${ }^{22}$ UNWCC, Draft Recommendation by the United Nations War Crimes Commission, Doc. A.43 (22 April 1947) 1; History of the UNWCC (n 3) 477.

${ }^{23}$ History of the UNWCC (n 3) 509.

${ }^{24}$ History of the UNWCC (n 3) 480; UNWCC, Minutes of the Eightieth Meeting, Doc. M.80 (3 October 1945) 9.

${ }^{25}$ History of the UNWCC (n 3) 481.

${ }^{26}$ Ibid., 509.

${ }^{27}$ Bassiouni (n 17) 550-551.
} 
towards the prosecution of war criminals before the International Military Tribunals in Nuremberg (IMT) and International Military Tribunals for the Far East (IMTFE).

\section{THE UNWCC AND THE PRINCIPLE OF COMPLEMENTARITY}

For the purpose of this article, 600 Commission documents were reviewed. One of the most striking discoveries was the number of similarities between the Commission's mission and the current structure and role of the International Criminal Court (ICC). ${ }^{28}$ The principle of complementarity embodied in the ICC seeks to ensure primary jurisdiction and accountability at the state level. The ICC is considered as a court of last resort. Its existence and codifying legislation are designed to support a cooperative process to end impunity for international crimes. Although the Rome Statute, the underlying legal authority for the ICC, does not offer a robust definition of the term 'complementarity', the Statute does specify that the ICC "shall be complementary to national criminal jurisdiction". ${ }^{29}$ Thus, the principle of complementarity places the ICC in a 'complementary' role to the national courts and does not circumvent the intrinsic responsibility of states to prosecute international crimes. ${ }^{30}$ The ICC is viewed as a secondary institution, which is empowered to act if and when domestic institutions are unable or unwilling to fulfill their obligation to prosecute international crimes.

The history of the principle of complementarity is often viewed within the early drafting stages of the Rome Statute as embodied in Draft Statute for an International Criminal Court with Commentaries. ${ }^{31}$ However, the majority of academics and commentators have said very little, if anything, about a much earlier debate on the

\footnotetext{
${ }^{28}$ The principle of complementarity before the International Criminal Court and the creation of the UNWCC will be considered, in detail, in an upcoming publication by the author Dr Mark Ellis, entitled Sovereignty and Justice: Creating Domestic War Crimes Courts within the Principle of Complementarity, which will be released in 2014.

${ }^{29}$ Rome Statute of the International Criminal Court, 2187 UNTS 90 (entered into force 1 July 2002) (Rome Statute). Article 1.

${ }^{30}$ M. S. Ellis, 'International Justice and the Rule of Law: Strengthening the ICC through Domestic Prosecutions' (2009) 1 Hague Journal on the Rule of Law 79, 81.

31 'Draft Statute for an International Criminal Court with Commentaries' (1994) 2 1 Yearbook of the International Law Commission 26.
} 
principle of complementarity during the creation and operation of the UNWCC between 1943 and 1948. It was actually the UNWCC that laid the ground for the current design and interpretation of the principle of complementarity.

The focus on complementarity was most prominent in the composition of the National Offices for each Allied country of the UNWCC. National Offices operated within each country and were comprised of its own nationals, "using its own endeavors to examine the atrocities and track the main offenders". ${ }^{32}$ As succinctly stated by Dr Marcel de Baer, a Belgian representative on the Commission, "[i]t cannot enough be stressed that if the National Offices wish to see a just punishment imposed upon these men they should investigate these cases themselves and bring charges against them". ${ }^{33}$ His remarks demonstrate the high-level of responsibility that was afforded to the National Offices and echo the fact that the national courts should try the majority of cases. ${ }^{34}$ De Baer's comments also reflected the essence of the Moscow Declaration, which stated:

Those German officers and men and members of the Nazi party who have been responsible for or have taken a consenting part in the above atrocities, massacres and executions will be sent back to the countries in which their abominable deeds were done in order that they may be judged and punished according to the laws of these liberated countries and of free governments which will be erected therein. ${ }^{35}$

In line with this, the Commission expressed that:

With the exception of major war criminals, whose offences have no particular geographical localization, war criminals, upon apprehension, will be sent back to the countries in which their crimes were committed in order that they may be judged by the courts of such countries. The mentioned countries thus have a paramount right to such criminals and their courts have primary jurisdiction. ${ }^{36}$

${ }^{32}$ UNWCC, Record of Conference held on May 6th 1945, between Members of the United Nations War Crimes Commission and Members of the United States Senate and House of Representatives, Doc. C.115 (24 May 1945) 2-3.

${ }^{33}$ UNWCC, Annex IV-Cooperation between National Offices and the War Crimes Commission, Doc. NOC.4 (2 June 1945) 2 (emphasis added).

${ }^{34}$ UNWCC, Notes of Unofficial Preliminary Meeting of the United Nations Commission for the Investigation of War Crimes (26 October 1943) $3<\mathrm{http}$ ://www. legal-tools.org/doc/ad8990/> accessed 11 December 2013.

35 Moscow Declaration (n 6) (emphasis added).

${ }^{36}$ UNWCC, Recommendation in favour of the establishment by Supreme Military Commanders of Mixed Tribunals for the Trial of War Criminals, Doc. C.52(1) (26 September 1944) 1 (emphasis added). 
Thus, it was the national courts that had "primary jurisdiction" to try war criminals. ${ }^{37}$ As mentioned earlier, the Commission was referred to as an "arbitrator", 38 an "intermediary" 39 and as an "advisor" 40 in the UNWCC documents. This demonstrates the "root idea of selfhelp" maintained by the UNWCC, that the Allied countries should each bring to justice those enemies who committed offences against their own nationals. ${ }^{41}$

It is interesting to note that the responsibilities of the Commission extended only to war criminals and not to those individuals who committed atrocities against nationals of their own country. ${ }^{42}$ This exception aimed to ensure that the Commission did not interfere with a nation and its own citizens ${ }^{43}$ and sought to protect a State's right to punish its own nationals. ${ }^{44}$ While recognizing that, in general, the "appropriate tribunals for the trial and punishment of such crimes will

${ }^{37}$ Notes of Unofficial Preliminary Meeting (n 34) 3; UNWCC, Draft Convention for the Establishment of a United Nations War Crimes Court, Doc. C.50(1) (30 September 1944) 1; Draft of a Note, Doc. A.32 (n 11) 2.

${ }^{38}$ UNWCC, Order of Trial of War Criminals whose delivery is asked for by more than one of the United Nations: Proposal that the Commission should arbitratePresented by $M$ de Baer, Doc. C.123 (13 June 1945) 1; UNWCC, Minutes of the Meeting of Committee III held on 29th January 1946, Doc. No. 3/46 (29 January 1946) 1-2; UNWCC, Annex VIII - Texts submittedby the Sub-Committee of the Meeting of National Offices Delegates, Doc. NOC.8 (2 June 1945) 1.

39 Annex $V$, Doc. NOC.5 (n 10) 2-3.

${ }^{40}$ Draft of a Note, Doc. A.32 (n 11) 4, 13; UNWCC Committee III, Notes of Meeting held on 3rd September 1945, Doc. No. 4/45 (3 September 1945) 2; Cablegram sent by Oldham to External Affairs (n 20).

${ }^{41}$ UNWCC, Annex VI-Chairman's Introductory Speech, Doc. NOC.6 (31 May 1945) 5.

${ }^{42}$ UNWCC, Preparation and Presentation of Case of War Crimes, Doc. C.87(1) (19 April 1945) 1.

${ }^{43}$ UNWCC, Report by Committee I on the Treatment of Quislings, Doc. C.61(1) (6 November 1944) 1.

${ }^{44}$ UNWCC, Amendment of Paragraph 1 of Committee III's Draft Recommendation Regarding the SA, SS, and the Gestapo (Document C35), Doc. C.35(1) (4 August 1944) 1; "Each of the United Nations has the right, either on the basis of its present criminal law or on the basis of new legislation, to punish its own nationals who became members of the S.A.; S.S.; or Gestapo, irrespective of their rank as members and of the territories in which they served. Each of the United Nations has also the right to punish German or foreign members of the above-mentioned organisations who have committed crimes in their territories" (emphasis added). The term "United Nations" refers to the Allied nations following the adoption of the Declaration by United Nations (signed 1 January 1942). 
be national courts of the United Nations", ${ }^{45}$ the Commission went even further and noted that the national courts should decide what laws and what procedure were applicable. ${ }^{46}$ Given that international law was still developing, members of the UNWCC argued for the importance of national jurisprudence and laws. Dr Radomir Zivković, a Yugoslavian representative on the Commission, stated that:

We should recognize clearly, in the first place, that there is no proper international law as there is a national law; and secondly, that there is, in a much lesser degree, an international criminal law. International law as a whole, as I have already said, is still in its infancy; and as regards international criminal law, it has not yet been born. That is a position we should not forget even for a second, because it leads us to the fundamental conclusion that to think on the lines of national law, and more especially on the lines of national criminal law, in questions that relate to international law, and more especially to international criminal law, is neither an unavoidable necessity nor even a correct process of legal thinking. ${ }^{47}$

Looking back to the discussions on complementarity at the UNWCC, it is clear that the Commission afforded a high-level of responsibility to the National Offices and domestic courts. The Commission sought to assist States, not dictate to them. States had the primary jurisdiction over the prosecution of war crimes.

\subsection{The Principle of Complementarity and the Creation of an International Court}

The UNWCC can also be seen as a precursor to the current structural and statutory relationship between the ICC and State Parties to the Rome Statute. Although not notable in the eyes of the public, the UNWCC actually discussed the idea of an international court to try war criminals. And at the center of this debate was the principle of complementarity. Although national courts were afforded primary jurisdiction, the UNWCC called for close cooperation between the Allied Nations and the Commission. For instance, the Commission stressed that major war criminals, as defined by the Moscow Declaration, should be tried by an international court. On the subject of high-level perpetrators, the Commission stated that:

${ }^{45}$ Draft Convention for the Establishment of a United Nations War Crimes Court, Doc. C.50(1) (n 37) 1 (emphasis added); Notes of Unofficial Preliminary Meeting (n 34) 3 .

46 Annex VI, Doc. NOC.6 (n 41) 5.

${ }^{47}$ UNWCC, Minutes of Thirty-sixth Meeting, Doc. M.36 (17 October 1944) 4 (emphasis added). 
The judging of a certain, be it limited, number of the most prominent criminals, such as HITLER, HIMMLER, GOEBBELS, GOERING, MUSSOLINI, CIANO, etc., etc., could take place much better by an International Criminal Court than by any National Court of Law, however high its standing and however undoubted, its integrity might be. It can even be said that the trial of these individuals if it is to give general satisfaction, can and may only take place through the medium of an International Organ. ${ }^{48}$

Furthermore, as the Allied courts were unable to try Germans who committed crimes in Germany, members of Commission argued that the creation of an international court would offer a solution; "[t]he campaign of racial extermination of the Jews has special features which do not generally fall within the scope of the National Offices, as for instance the case of German Jews murdered in Germany". ${ }^{49}$

This same argument for an international court with jurisdiction over high-level perpetrators and over the most serious of crimes is also echoed in the Rome Statute. This point is expressly stated in the Statute's Preamble, as "the most serious crimes of concern to the international community as a whole must not go unpunished" and under Article 1 of the Statute, which states that the ICC "shall be a permanent institution and shall have the power to exercise its jurisdiction over persons for the most serious crimes of international concern, as referred to in this Statute, and shall be complementary to national criminal jurisdictions". 50

The discussions on the creation of an international court followed an earlier debate in 1937 in the League of Nations, which focused on the creation of the Convention for the Creation of an International Criminal Court. ${ }^{51}$ Under this Convention, the court would be a permanent body that would deal with willful acts against heads of states, destruction of public property of another State, terrorist activities and war crimes - when a State might "prefer to surrender

${ }^{48} \mathrm{UNWCC}$, Report on the Constitution of and the Jurisdiction to be conferred on an International Criminal Court (submitted to the London Assembly by Dr JM de Moor), Doc. SC II/3 (25 February 1944) 4.

49 Annex VI, Doc. NOC.6 (n 41) 6.

${ }^{50}$ Rome Statute (n 29) Preamble and Article 1.

${ }^{51}$ League of Nations, 'Convention for the Prevention and Punishment of Terrorism and the Convention for the Creation of an International Criminal Court (Geneva, 16 November 1937)' (1938) 19 League of Nations Official J 36; UNGA, Historical Survey of the Question of International Criminal Jurisdiction - Memorandum submitted by the Secretary-General, UN Doc. A/CN.4/7/Rev.1 (1949) 16-18; History of the UNWCC (n 3) 440-441. The French government first raised the idea in a letter to the League of Nations in 1934. 
that person to an international court". ${ }^{52}$ The Convention aimed to address "offences of an international character". ${ }^{53}$ However, although the Convention was adopted, it never entered into force. ${ }^{54}$ The London International Assembly adopted an initial draft of the proposed court - the Draft Convention for the Creation of an International Criminal Court - in February $1944 .{ }^{55}$ In April 1944, the American delegates drafted the Draft Convention on the Trial and Punishment of War Criminals, ${ }^{56}$ which took the London International Assembly's Draft Convention into account. ${ }^{57}$ According to Mohamed El Zeidy, the Draft Convention on the Trial and Punishment of War Criminals "retained the jurisdiction of national courts", and the court was designed to try cases "where national courts lacked jurisdiction under international law or as a result of a gap in domestic legislation". ${ }^{58}$ Importantly, this draft served as the basis of future discussions on the creation of a war crimes court. ${ }^{59}$

The Draft Convention on the Trial and Punishment of War Criminals was redrafted following several recommendations. ${ }^{60}$ The end result was the Draft Convention for the Establishment of a United Nations War Crimes Court, ${ }^{61}$ which reflected the work of the UNWCC and clearly shows that it played an antecedent role to the

\footnotetext{
${ }^{52}$ History of the UNWCC (n 3) 440.

${ }^{53}$ UNWCC, Draft Convention for the Creation of an International Criminal Court, submitted to the London International Assembly, Doc. II/2 (14 February 1944).

${ }^{54}$ History of the UNWCC (n 3) 440-441.

${ }^{55}$ Draft Convention for the Creation of an International Criminal Court, submitted to the London International Assembly, Doc. II/2 (n 53).

${ }^{56}$ UNWCC, Draft Convention on the Trial and Punishment of War Criminals, Doc. II/11 (14 April 1944).

${ }^{57}$ El Zeidy notes that although the Draft Convention was "inspired by the League of Nations" Draft Convention (1937), there is no "direct evidence to suggest that it was intended, to base it on the 1937 League of Nations provision" relating to a complementarity mechanism (M. M. El Zeidy, The Principle of Complementarity in International Criminal Law; Origin, Development and Practice (Leiden, Martin Nijhoff Publishers, 2008) 72).

${ }^{58}$ Ibid., 71.

${ }^{59}$ Ibid., History of the UNWCC (n 3) 443.

${ }^{60}$ Report, Doc. SC II/3 (n 48) 4.

${ }^{61}$ Draft Convention for the Establishment of a United Nations War Crimes Court, Doc. C.50(1) (n 37); Original draft by Committee II of the UNWCC, Draft for the Establishment of a United Nations Joint Court, Doc. C.50 (22 September 1944). See UNWCC, Explanatory Memorandum to Accompany theDraft Convention for the Establishment of a United Nations War Crimes Court, Doc. C.58 (6 October 1944).
} 
Rome Statute on the complementarity principle. The Preamble of the Draft Convention for the Establishment of a United Nations War Crimes Court reflects the sentiment of complementarity, in part, that:

Recognizing that in general the appropriate tribunals for the trial and punishment of such crimes will be national courts of the United Nations,

Mindful of the possibility that cases may occur in which such crimes cannot beconveniently or effectively punished by a national court,

Have decided to set up an Inter-Allied Court before which the Governments of the United Nations may at their discretion bring to trial persons accused of an offence to which the Convention applies in preference to bringing them before a national court. ${ }^{62}$ As stated earlier, the Preamble to the Rome Statute affirms the same complementary principle, stating that the "most serious crimes of concern to the international community as a whole must not go unpunished and that their effective prosecution must be ensured by taking measures at the national level and by enhancing international cooperation". ${ }^{63}$

Thus, from the earliest stage of the modern drafting process for the Rome Statute, the conveners, knowingly or unknowingly, followed the precedence of the UNWCC and established that the ICC should have jurisdiction over only the most "serious crimes", emphasizing national prosecutions. ${ }^{64}$ As initially drafted, the Preamble of the Rome Statute, together with key commentary and articles, were clear in stating that the Court would complement national criminal justice systems if and when a suspect had no prospect of being tried at the national level or a fair trial was not possible. ${ }^{65}$

${ }^{62}$ Draft Convention for the Establishment of a United Nations War Crimes Court, Doc. C.50(1) (n 37) 1 (emphasis added).

${ }^{63}$ Rome Statute (n 29), Preamble.

${ }^{64}$ UNGA 'Report of the International Law Commission on the Work of its FortySixth Session, Draft Statute for an International Criminal Court' UN Doc. A/49/355 (1 September 1994), Preamble: "The States Parties to this Statute; Desiring to further international cooperation to enhance the effective prosecution and suppression of crimes of international concern, and for that purpose to establish an international criminal court; Emphasizing that such a court is intended to exercise jurisdiction only over the most serious crimes of concern to the international community as a whole; Emphasizing further that such a court is intended to be complementary to national criminal justice systems in cases where such trial procedures may not be available or may be ineffective; Have agreed as follows...".

${ }^{65}$ See 'Draft Statute for an International Criminal Court with Commentaries' (n 31) for commentary to the Preamble; UNGA 'Report of the International Law Commission on the Work of its Forty-Sixth Session (1994)' (22 February 1995) UN Doc. A/CN.4/ 464/Add.1, para. 7: "Above all, it was emphasised that the Draft Statute must provide further assurances that the proposed Court would be complementary to national courts and that the new system would not undermine existing law enforcement efforts". 
Most important, and most relevant, to the current complementarity structure of the ICC is the fact that the UNWCC made certain that states that were unable or unwilling to try alleged war criminals could surrender the suspects so as to try them by an international court. The Rome Statute creates the same set of jurisdictional guidelines, which limits the authority of the ICC and ensures that the Court shall not hear a case if the relevant state has made a decision to act. Under the Rome Statute, the ICC gains jurisdiction over a situation if the State is unwilling or unable to carry out an effective investigation or prosecution of a case. ${ }^{66}$ The same holds true for the UNWCC.

The Chairman of the UNWCC, Sir Cecil Hurst, stressed that:

There was need of both courts, though not simultaneously. The cases so far could all be tried by national courts under the Moscow system; but there was a class of persons who had directed criminal policies on the high-level, or who could not be adequately punished by some national courts, and for them an inter-allied court was needed. ${ }^{67}$

This was clearly demonstrated during Commission meetings, as some delegates raised concerns over the inadequacy of ordinary criminal law to deal with violations of the laws and customs of war. The French representative, Professor André Gros, stated that:

There is unanimous agreement as to the competence of the national courts; indeed that view is imposed on us by the Moscow Declaration. But there remain to be considered:

(b) The criminals whom the governments are unable to punish (owing to the lack of national laws), or whom they do not wish to try in their own courts-preferring to send them before an international court. ${ }^{68}$

The Commission accepted the Draft Convention for the Establishment of a United Nations War Crimes Court on 26 September $1944 .{ }^{69}$ However, it never entered into force following objections from the

\footnotetext{
${ }^{66}$ Rome Statute (n 29) Articles 17(1)(a) states that a case is inadmissible where "the case is being investigated or prosecuted by a State which has jurisdiction over it, unless the State is unwilling or unable genuinely to carry out the investigation or prosecution".

${ }^{67}$ UNWCC, Minutes of the Thirtieth Meeting, Doc. M.30 (5 September 1944) 2 (emphasis added).

${ }^{68}$ UNWCC, Minutes of the Thirty-first Meeting, Doc. M.31 (12 September 1944) 3 (emphasis added).

${ }^{69}$ History of the UNWCC (n 3) 450; Historical Survey (n 51) 20.
} 
British delegates. ${ }^{70}$ Although not adopted, the Draft Convention clearly illustrates that the drafters envisaged the principle of complementarity. The Commission recognized that national courts are the courts of choice, and specified that in cases where national courts are unable to deal with certain crimes, the Allied Nations may choose to bring such persons before an international court.

\section{THE RIGHT TO A FAIR TRIAL AND THE UNWCC}

The covenant right to a fair trial is protected under Article 14 of the International Covenant on Civil and Political Rights (ICCPR) and by other international instruments. ${ }^{71}$ Under international human rights law, the accused is entitled to a fair and public hearing, within reasonable time, before an impartial and independent tribunal established by law and has the right to be presumed innocent until proven guilty. Today's fair trial rights also encompass the right to be informed of the charge, the right to legal counsel or the option of selfrepresentation, the right to have "adequate time and facilities for the preparation of his defence", ${ }^{72}$ the right to trial without undue delay, the right to examine witnesses, the right to understand the trial in a language that he/she understands and the right to appeal. Given that most of the international human rights instruments that protect the right to a fair trial were written after the creation of the UNWCC, it is important to discuss the nature of the right to a fair trial at the time of the Commission's mandate.

\footnotetext{
${ }^{70}$ UNWCC, Letter dated 4 January 1945 from Mr Eden to Sir Cecil Hurst dealing with certain proposals submitted by the Commission to the Government, Doc. C.68 (10 January 1945) 2.

${ }^{71}$ International Covenant on Civil and Political Rights (adopted 16 December 1966, entered into force 23 March 1976) 999 UNTS 171 (ICCPR), Article 14; Universal Declaration of Human Rights (adopted 10 December 1948) UNGA Res 217 A(III) (UDHR) Articles 10 and 11; African Charter on Human and Peoples' Rights (adopted 27 June 1981, entered into force 21 October 1986) (1982) 21 ILM 58 Article 7; American Declaration of the Rights and Duties of Man, OAS Res XXX adopted by the Ninth International Conference of American States (1948) reprinted in Basic Documents Pertaining to Human Rights in the Inter-American System OEA/Ser L V/II.82 Doc 6 Rev 1 at 17 (1992) Article 8; Convention for the Protection of Human Rights and Fundamental Freedoms (European Convention on Human Rights, as amended) (ECHR) Article 6; Convention on the Rights of the Child (adopted 20 November 1989, entered into force 2 September 1990) 1577 UNTS 3, Article 40(2)(b)(iii); Rome Statute (n 29) Articles 8(2), 64(2), 67 and 69.

${ }^{72}$ ICCPR (n 71) Article 14(3)(b).
} 
Judge Patrick Robinson argues that the "roots of the basic principles of the right to fair trial" date back to the first written code of laws, Lex Duodecim Tabularum, which was written around 455 BC in the Roman Republic. ${ }^{73}$ Elements of the right to a fair trial are also found in the Magna Carta Libertatum (1215), the Sixth Amendment of the United States Constitution (1791), the French Declaration of the Rights of Man (1789) and in the Treaty of Versailles (1919). ${ }^{74}$ Therefore, one could argue that the right to a fair and impartial trial was recognized by the Allied nations at the time of the trials.

The UNWCC documents show that 24,760 persons were tried in Europe and in the Far East between the summer of 1945 and March 1948. Of those tried, $71 \%(17,568)$ were imprisoned and $8 \%(1,999)$ were sentenced to death. This means that $79 \%(19,567)$ of those charged were convicted, and that only $21 \%(5,193)$ were acquitted. Consequently, I have some concerns over the rights of those accused during the war crimes trials. ${ }^{75}$

The Moscow Declaration was a key document for the trial of "minor" war criminals, which declared that those who committed crimes will be "judged and punished according to the laws" of the countries where the crimes were committed. ${ }^{76}$ However there is no

${ }^{73}$ Judge P. Robinson, 'The Right to Fair Trial in International Law, with Specific Reference to the Work of the ICTY' (2009) 3 Berkeley J. Int'l L. 1-5.

${ }^{74}$ French Declaration of the Rights of Man (1789) Articles 6-9; The Treaty of Peace between the Allied and Associated Powers and Germany (signed 28 June 1919) Part VII, Articles 227-230; Under the Geneva Convention Relative to the Treatment of Prisoners of War (adopted 27 July 1929) Articles 61-67, it considered a war crime to deny fair trial rights to a prisoner of war.

${ }^{75}$ History of the UNWCC (n 3) 518. According to the UNWCC documents, nearly 2,000 cases were tried and 36,529 persons were charged by the Governments and listed by the Commission of which, 24,453 were charged as war criminals (History of the UNWCC (n 3) 509). There are no statistics available regarding the war crimes trials in Russia, the Soviet Zone of Germany, Hungary, Roumania (Romania) or Bulgaria and the number of Polish and Czechoslovakian cases were not recorded. Therefore, the above figures represent cases held by the United States, Britain, France, Greece, the Netherlands, Norway, Poland, and Yugoslavia (History of the $U N W C C$ (n 3) 517). Given that there are several inconsistencies with the exact number of those charged, further research is needed to clarify the exact number of trials and of those charged. See UNWCC, Law Reports of Trials of War Criminals: Selected and Prepared by the United Nations War Crimes Commission (Vol. XV) (His Majesty's Stationery Office 1947) 203; History of the UNWCC (n 3) 508-519; UNWCC, Final Statistical Progress Report (1st February 1944 to end of March 1948) Doc. C.267 (21 April 1948).

76 Moscow Declaration (n 6). 
mention of the rights of the accused in this declaration. The Allied nations were initially divided on the method of punishment for the Axis forces. One option was that those who were guilty of war crimes should be punished without trial. The Russian and British delegates were in favour of the summary execution of military leaders. However, the American delegates resisted this option and insisted that those accused should be given the opportunity to stand trial. ${ }^{77}$

The National Offices submitted cases to the Commission, using a prescribed form that asked, "what will be the probable defence?" and "can the offender be put on trial with a reasonable probability of conviction?"78 In determining whether a prima facie case existed, Committee I asked, "is there good reason to assume that if put on trial, the alleged offender would be convicted?" ${ }^{, 79}$ However, Committee I did not ask whether the suspect would be afforded a fair trial. The fact is that the Committee had neither facilities nor authority to solicit refutable information or evidence from the accused or from those representing the accused. The Committee had to "rely entirely upon the good faith, accuracy and diligence, of the various member Governments in presenting cases involving bona fide war crimes". ${ }^{80}$ Committee I examined 8,178 cases which listed nearly 37,000 persons. ${ }^{81}$ However, only a small number of cases were reconsidered and only three names were removed from the list of war criminals. ${ }^{82}$ This clearly indicated the high degree of presumption given to the National Offices.

\subsection{Review of Fair Trial Standards During the National Trials}

Despite the reliance on the National Offices to ensure fair trial standards, it is helpful to review several cases in order to ascertain the rights afforded, if any, to the accused in the minor war crimes trials

77 A. Narayanan, 'Japanese Atrocities and British Minor War Crimes Trials After World War II in the East' (2006) 33 Jebat: Malaysian J. of History, Politics \& Strategic Studies 1, 5; 'Foreword by the Right Honourable Viscount Simon' in C. Sleeman and S. C. Silkin (eds.) TheDouble Tenth Trial: The Trial of Sumida Haruzo and Twenty Others (London, William Hodge \& Co., 1951) xiii-xiv.

${ }^{78}$ History of the UNWCC (n 3) 478.

${ }^{79}$ History of the UNWCC (n 3) 482.

${ }^{80}$ Ibid.

${ }^{81}$ History of the UNWCC (n 3); Progress Report, Doc. C.267 (n 75 ) 3.

${ }^{82}$ History of the UNWCC (n 3) 484. 
held by the Allied nations. ${ }^{83}$ The cases mentioned below are those which were held by the Allied nations in Europe and in the Far East, but do not include those of the IMT, the IMTFE or the Allied Control Council Law No. 10 trials. This is because the UNWCC was not "institutionally linked to the IMT [or IMTFE] or to the Subsequent Proceedings by the Allied occupation forces in Germany pursuant to Allied Control Council Law No. 10, where each ally had its own investigations and teams". ${ }^{84}$

\subsubsection{Independence}

One of the basic elements of the right to a fair trial is the right to appear before an independent and impartial tribunal established by law. In this respect, the United States Military Tribunal stated that "[a] fair trial before a judicial body affords the surest protection against arbitrary, vindictive or whimsical application of the right to shoot human beings in reprisal". ${ }^{85}$ Nonetheless, given that the trials were held by the victorious Allied nations, the impartiality of the trials could be called into question, as there were some examples of anti-Japanese sentiment in the trials held following the end of World War II. ${ }^{86}$ For instance, during the Silver Mine Bay trial before the British Military Court in Hong Kong, the Presiding Judge sentenced the accused to death and stated that they were "members of a black and evil race". ${ }^{87}$ However, this was the first trial in Hong Kong

${ }^{83}$ There are a number of elements of the right to fair trial that are not discussed in this article, for instance the right to a public hearing, equality before arms, the right to compensation for a miscarriage of justice, and the right to freedom from double jeopardy. Further study that deals with this issue should incorporate these elements to provide a better picture of the fair trial rights of the accused in the war crimes trials.

${ }^{84}$ Bassiouni (n 17) 550.

${ }^{85}$ UNWCC, 'The Hostages Trial: The Trial of Wilhelm List and Others, United States Military Tribunal and Others 8 July 1947-19 February 1948' Law Reports of Trials of War Criminals: Selected and Prepared by the United Nations War Crimes Commission (Vol. IX) (His Majesty's Stationery Office 1947) 64.

${ }^{86}$ See A. Narayanan, 'Second World War Japanese Atrocities and British Minor War Crimes Trials: The Issue of Fair Trial in Four Selected British Minor Crimes Trials in Malaya and Singapore in 1946-1947' (DPhil thesis, University of Wales 2003).

${ }^{87}$ Trial of Lieutenant Kishi Yasuo, British Military Court in Hong Kong, Case No. WO235/993, Transcript 531 Slide 558 (as cited in S. Linton, 'Rediscovering the War Crimes Trials in Hong Kong, 1946-1948' (2012) 13 Melbourne Journal of International Law 1, 61). 
following the end of the war and such anti-Japanese sentiments were not repeated in other cases. ${ }^{88}$

From the UNWCC documents reviewed for this article, it is evident that a number of the Allied Nations sought to ensure that the trials did not amount to victors' justice. For example, Dr H. V. Evatt, the Australian Attorney General and Minister for External Affairs, stated that the trials were "actuated by no spirit of revenge, but by profound feelings of justice to ensure that the next generation of Australians is spared such frightful experiences". ${ }^{89}$ A Canadian Military Court found that:

The accused is not to be prejudiced because he is a member of an enemy force and the Court is not concerned with public opinion expressed in the press or elsewhere or with questions of policy or expediency. This is a judicial enquiry conducted according to our conception of justice that is to say, conscientiously and impartially, without fear or favour. ${ }^{90}$

\subsubsection{Right of Appearance}

The right to be present at trial was provided for under Rule 40 (A) of the Rules of Procedure for British Military Courts and is also found in the regulations of the United States Military Commissions, the Military Tribunals and the Military Government Courts. Such provisions also allowed the accused to provide evidence before the court, provided that his testimony would be subjected to cross-examination. ${ }^{91}$ During the trial of Shigeru Ohashi, the Judge Advocate stated that the accused "should have full opportunity to give his own ver-

${ }^{88}$ Linton (n 87) 62.

${ }^{89}$ H. V. Evatt, 'Japanese Atrocities and War Crimes, 10 September 1945' in H. V. Evatt, Australia in World Affairs (Sydney, Angus and Robertson, 1946).

${ }^{90}$ L. C. Green 'Canada's Role in the Development of the Law of Armed Conflict' (1980) 18 The Canadian Yearbook of International Law 91, 105; See 'The Abbaye Ardenne Case: Trial of S. S. Brigadeführer Kurt Meyer, Canadian Military Court, Aurich, Germany (10-28 December 1945)' Law Reports of Trials of War Criminals: Selected and Prepared by the United Nations War Crimes Commission (Vol. IV) (His Majesty's Stationery Office 1947).

${ }^{91}$ UNWCC, Report submitted to the United Nations Economic and Social Council on Information Concerning Human Rights Arising from Trials of War Criminals, UN Doc. E/CN.4/W.19 (15 May 1948) 251; See UNWCC, Yugoslav War Crimes Legislation, Doc. Misc. No. 60 (9 December 1946) 5. 
sion of the case and produce evidence to support it". ${ }^{92}$ However, the court may 'proceed in the absence of the accused' if 'the accused has applied for and been granted permission to be absent; or if the accused is believed to be a fugitive from justice'. ${ }^{93}$ After a review of nearly 600 documents for this article, there was no record of in absentia trials.

\subsubsection{Presumption of Innocence}

The right to be presumed innocent until proven guilty is a vital element of the right to a fair trial. The Judge Advocate, in Ohashi, stated that "[t]he Court should satisfy itself that the accused is guilty before awarding punishment...", but there must be "consideration by a tribunal...who will endeavour to discard any preconceived belief in the guilt of the accused or prejudice against him". ${ }^{44}$ However, Professor Gavan McCormack has argued that, in the Burma-Thai DeathRailway trials, the presumption of guilt was strong. ${ }^{95}$

\subsubsection{Awareness of Charges}

The right to know the substance of the charge was provided for under Rule 15 (A) of the Rules of Procedure for the British Military Courts and Article 179 of the French Code de Justice Militaire. ${ }^{96}$ The United States Military Commissions in the Pacific Theater also stated that the accused is entitled "[t]o have in advance of trial a copy of the charges and specifications, so worded as clearly to apprise the accused of each offense charged". ${ }^{97}$ However, in a number of cases, defense

${ }^{92}$ UNWCC, 'Trial of Sergeant-Major Shigeru Ohashi and Six Others, Australian Military Court, Rabaul, 20-23 March 1946' Law Reports of Trials of War Criminals: Selected and Prepared by the United Nations War Crimes Commission (Vol. V) (His Majesty's Stationery Office 1947) 30; Law Reports of Trials of War Criminals (Vol. XV) (n 75) 163; Law Reports of Trials of War Criminals (Vol. V) (n 92) 30.

${ }^{93}$ UNWCC, Courts and Criminal Procedure in Germany Under Allied Military Government - Note by the Legal Officer (Dr Schwelb), Doc. C.132 (28 June 1945) 5.

94 'Trial of Ohashi and Six Others' (n 92) 30; Law Reports of Trials of War Criminals (Vol. XV) (n 75) 164.

${ }^{95}$ G. McCormack, 'Apportioning the Blame: Australian Trials for Railway Crimes' in G. McCormack and H. Nelson (eds.) The Burma-Thailand Railway: Memory and History (Chiang Mai, Silkworm Books, 1993) 112.

96 Report submitted to the United Nations (n 91) 251.

${ }^{97}$ UNWCC, United States Provisions regarding Military Commissions in the Pacific Theater of Operations, Doc. Misc. No. 41 (19 August 1946), Article 14. 
counsel raised the issue that some of the charge sheets were vague, not specific, and often duplicative of the charges. ${ }^{98}$

\subsubsection{Right to Counsel}

The fundamental right to counsel was also prevalent in the trials. Under Regulation 7 of the Royal Warrant, counsel could represent a defendant before British Military Courts, while under Article 5(b) of the Pacific December Regulations the accused was entitled to representation or could conduct his own representation. ${ }^{99}$ Similarly, under Article 14(b) of the China Regulations, the accused could represent himself or be represented by counsel of his choice or by a court appointed representative. ${ }^{100}$ The United States Military Commission stated that "[i]f the accused fails to designate his counsel; the commission shall appoint competent counsel to represent or advise the accused". ${ }^{101}$

However, there were issues associated with the right to counsel in some of the trials. For instance, in the Yamashita case "[t]he only basic protection accorded to the petitioner had been representation by able Counsel: yet this had lost much of its value because of the denial of reasonable opportunity for them to perform their function". ${ }^{102}$ Richard L. Lael argues that given the "unfamiliarity with war crimes proceedings", "questionable decisions" were made during

\footnotetext{
${ }^{98}$ See Trial of Sergeant Hanada Zenji and Three Others, British Military Court in Hong Kong, Case No. WO235/895 (as cited in Linton (n 87) 63).

99 Royal Warrant, Army Order 81/45, (14 June 1945) as amended by Army Orders 127/1945, 8/1946 and 24/1946; 'Regulations Governing the Trial of Accused War Criminals' (Pacific Regulations) of 5 December 1945; See UNWCC 'The German High Command Trial: Trial of Wilhelm Von Leeb and Thirteen Others, United States Military Tribunal, Nuremburg, 30 December 1947-28 October 1948' Law Reports of Trials of War Criminals (Vol. XII) 62-63; UNWCC, British Regulations for the Trial of War Criminals by Military Courts: Note by the Legal Officer (Dr Schwelb) Doc. C.131 (27 June 1945).

${ }^{100}$ Report submitted to the United Nations (n 91) 252-253; China Regulations of 21 January 1946; The provision is also covered under the Polish Decree of 31 October 1946 on the establishment of a Supreme National Tribunal and under the Norwegian General Law No. 5 of 1 July 1887 on Criminal Procedure (Articles 99, 101 and 107).

${ }^{101}$ United States Provisions, Doc. Misc. No. 41 (n 97).

${ }^{102}$ UNWCC, 'The Trial of General Tomoyuki Yamashita, United States Military Commission (8 October-7 December 1945) and the Supreme Court of the United States (4 February 1946)' Law Reports of Trials of War Criminals (Vol. IV) (n 90) 55.
} 
the Yamashita trial. ${ }^{103}$ Lord Wright, Chairman of the UNWCC, also expressed concern over the capability of the defense counsel during one of the trials held in Yokohama, Japan. He stated that the "defence counsel were much too slow and leisurely in their proceedings and were wasting a great deal of time". ${ }^{104}$ On the other hand, following a review of a number of cases before the Hong Kong war crimes courts, Dr Suzannah Linton found that assistance and time was given to the defense counsel to have documents translated and to locate witnesses and that the courts were patient with Japanese counsel who were unfamiliar with the adversarial system. ${ }^{105}$

\subsubsection{Adequate Time and Facilities for the Preparation of the Defense} With regards to the right to have adequate time and facilities for the preparation of defense, British Military Courts favored an expeditious trial. It was stressed that "[n]o attempt will be made, of course, to prevent anything being said which is in the interests of justice, but we wish to proceed with the greatest possible speed, because there are large numbers of other persons awaiting trial, and it is unfair that they should be kept in custody without trial longer than can be helped". ${ }^{106}$ The United States Military Commissions "confined" each trial strictly to a fair, expeditious hearing on the issues raised by the charges, excluding irrelevant issues or evidence and preventing any unnecessary delay or interference. ${ }^{107}$ However, this indict was not always followed. General Tomoyuki Yamashita was the first prisoner to stand trial before the United States Military Tribunal in Manila and General Douglas MacArthur was determined to speed up the trial of Yamashita following orders from Washington to proceed "without avoidable delay". ${ }^{108}$ As a result, the court instructed the defense counsel to shorten the cross-examination of witnesses and ordered that criticisms of inaccurate translations were not to be discussed in open court. ${ }^{109}$

In the Yamashita decision, Mr Justice Rutledge and Mr Justice Murphy both dissented and questioned the applicability of the Fifth

${ }^{103}$ R. L. Lael, The Yamashita Precedent: War Crimes and Command Responsibility, (Wilmington, Scholarly Resources Inc., 1982) ix.

${ }^{104}$ UNWCC, Letter sent from Lord Wright to General Green, Judge Advocate General, Washington, DC, USA on 8 July 1946, Doc. C.211 (16 July 1946) 2.

105 Linton (n 87) 62.

106 'The Trial of Yamashita' (n 102) 83.

107 United States Provisions, Doc. Misc. No. 41 (n 97) Article 13(a).

${ }^{108}$ Lael (n 103) 137.

109 Ibid. 
Amendment of the United States Constitution to the case and the "alleged denial of adequate opportunity for the preparation of Yamashita's defence". ${ }^{110}$ Mr Justice Murphy stated that:

The failure of the military commission to obey the dictates of the due process requirements of the Fifth Amendment is apparent in this case... No military necessity or other emergency demanded the suspension of the safeguards of due process. Yet [the] petitioner was rushed to trial under an improper charge, given insufficient time to prepare an adequate defence, deprived of the benefits of some of the most elementary rules of evidence and summarily sentenced to be hanged. ${ }^{111}$

All of this was done without any thorough investigation and prosecution of those immediately responsible for the atrocities, out of which might have come some proof or indication of personal culpability on petitioner's part. ${ }^{12}$

By this flexible method a victorious nation may convict and execute any or all leaders of a vanquished foe, depending upon the prevailing degree of vengeance and the absence of any objective judicial review. ${ }^{113}$

\section{Mr Justice Rutledge stated that:}

I cannot believe in the face of this record that the petitioner has had the fair trial our Constitution and laws command. ${ }^{114}$

It is outside our basic scheme to condemn men without giving reasonable opportunity for preparing defence; in capital or other serious crimes to convict on official documents...; affidavits;...documents or translations thereof; diaries...photographs, motion picture films and...newspapers; or on hearsay, once, twice or thrice removed, more particularly when the documentary evidence or some of it is prepared ex parte by the prosecuting authority and includes not only opinion but conclusions of guilt. Nor in such cases do we deny the rights of confrontation of witnesses and crossexamination. ${ }^{115}$

\subsubsection{Rules of Evidence}

According to the UNWCC, the rules of evidence applied in minor war crimes trials were to be "less technical than those governing the proceedings of courts conducting trials in accordance with ordinary criminal law". ${ }^{116}$ The UNWCC stressed that such measures did not

\footnotetext{
110 'The Trial of Yamashita' (n 102) 2.

111 Ibid.

112 'The Trial of Yamashita' (n 102) 54.

113 Ibid.

${ }^{114}$ Ibid.

115 'The Trial of Yamashita' (n 102) 55.

${ }^{116}$ Report submitted to the United Nations (n 91) 260; 'The Trial of Yamashita' (n
} 102) 81 . 
mean that the trial against the accused should be unfair but the Commission did stress that its aim was "to ensure that no guilty person escape[d] punishment by exploiting technical rules". ${ }^{117}$ Given that many witnesses returned to their homes, disappeared, or died, and the impracticability of transporting witnesses, ${ }^{118}$ affidavit evidence was heavily relied on during the war crimes proceedings.

For the British Military Courts, Section 8(1)(b) of the Regulations Annexed to the Royal Warrant allowed for "any document purporting to have been signed or issued officially by any member of any Allied or enemy force or by any official or agency of any Allied, neutral or enemy government, [to] be admissible as evidence without proof of the issue or signature thereof". ${ }^{119}$ The Regulations Annexed to the Royal Warrant also stated that a military court was permitted to "take into consideration any oral statement or any document appearing on the face of it to be authentic, provided the statement or document appears to the court to be of assistance in proving or disproving the charge". ${ }^{120}$ Similarly, under Section 16 of the Regulations Governing the Trial of War Criminals, the United States Military Commission allowed the admission of any evidence which "would be of assistance in proving or disproving the charge", ${ }^{121}$ "without any of the usual modes of authentication". ${ }^{22}$ It was the Court's duty to determine the weight of the evidence. However, various defendants complained that the use of affidavit evidence meant that they were unable to cross-examine witnesses. ${ }^{123}$ The UNWCC also supported the admission of hearsay evidence, as the war crimes trials were not held before lay jurors, but before judges

117 'The Trial of Yamashita' (n 102) 260; Report submitted to the United Nations (n 91) 273.

118 UNWCC, Polish Progress Report and Plans Relating to War Criminals, Doc. A.38 (11 March 1947) 1.

119 British Regulations Annexed to the Royal Warrant, Section 8(1)(b) as inserted by Army Order 24 of 1946.

120 Ibid.

${ }^{121}$ Regulations Governing the Trial of War Criminals (Pacific Regulations), Section 16.

122 'The Trial of Yamashita' (n 102) 57.

${ }^{123}$ See Petition in Trial of Sergeant Major Yokohata Toshiro, British Military Court in Hong Kong, Case No. WO235/1117 Transcript 12 Slide 19; Closing Statement in Nakano Junichi, British Military Court in Hong Kong, Case No. WO235/1044 8 Slide 451; Trial of Toda Mitsugu and Eight Others, British Military Court in Hong Kong, Case No. WO235/1028 (28 May 1947) (as cited in Linton (n 87) 63); Report submitted to the United Nations (n 91) 264-267. 
who were capable of assessing the weight of the evidence before them. ${ }^{124}$

A number of scholars have now accessed the overall evidentiary approach advocated by the Commission and their conclusions are mixed. For instance, Professor Gavan McCormack has argued that, in the Burma-Thai Death-Railway trials, the "standards of proof were low... and the rules of evidence were applied to make a heavy burden for [the] defence". ${ }^{125}$ Arujunan Narayanan evaluated the fairness of four trials before the British Military Courts in the Far East; the Penang Kempetai case, the Double Tenth trial, the trial Gozawa Sadaichi and Nine Others and the Singapore Chinese Massacre trials. ${ }^{126}$ Narayanan found that, in general, the trials were conducted fairly. However, there were issues relating to the admission of affidavit evidence and the subsequent lack of cross-examination. ${ }^{127}$ An Australian military lawyer, Major George Dickinson argued that the relaxation of the rules of evidence for the Australian war crimes trials demonstrated "the apparent intention of depriving an accused person of the safeguard recognized by reasonable men and eminent lawyers as the basis of a fair trial in the Western World". ${ }^{128}$ However, in the Hostages trial, the United States Military Tribunal stressed the right to a fair trial in relation to admittance of evidence and stated that:

Any other interpretation would seriously affect the right of the defendants to a fair and impartial trial. The interpretation thus given and consistently announced throughout the trial by this Tribunal is not an idle gesture to be announced as a theory and ignored in practice - it is a substantive right composing one of the essential elements of a fair and impartial adjudication. ${ }^{129}$

\subsubsection{The Right to Comprehend Court Proceedings}

Considering the complexity of the cases and the diversity of nationalities among the accused, the right of the accused to understand the pro-

124 'The Trial of Yamashita' (n 102) 81; UNWCC, 'Trial of Friedrich Flick and Five Others, United States Military Tribunal Nuremburg, 20 April-22 December 1947' Law Reports of Trials of War Criminals (Vol. IX) (n 85) 16: "A fair trial does not necessarily exclude hearsay testimony and ex parte affidavits"; Report submitted to the United Nations (n 91) 269.

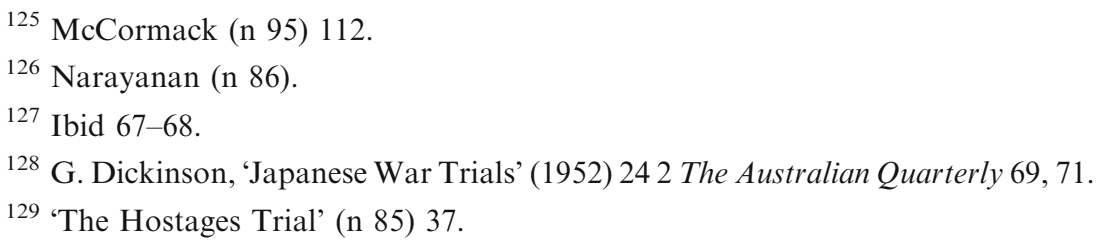


ceedings is fundamental to a fair trial. Under Article 14(d) of the Pacific September Regulations, an accused before a United States Military Commission was entitled "[t]o have the charges and specifications, the proceedings and any documentary evidence translated when he is unable otherwise to understand them". ${ }^{130}$ During the Belsen trial, held before a British Military Court, the Judge Advocate "advised the Court that he did not think that anybody should waive the rights of a person who did not understand a language when serious accusations of fact were being made". ${ }^{131}$ Therefore, the evidence of a German witness was translated into Polish, so the defendant and his counsel could fully understand the testimony. However, Dr Taseusz Cyprian, a Polish representative on the Commission, noted that, during the Belsen trial, the defence "were greatly hampered by the necessity of relying on interpreters". ${ }^{132}$ In the Scuttled U-Boats case, which was also held before a British Military Court, the defending Counsel sought the translation of the entire proceedings into German and expressed that the defense would address the Court in a language understood by the defendants. However, the Judge Advocate stressed that "the language of the Court is English" and, therefore, the Court would not normally be addressed in German or another language. ${ }^{133}$ The Royal Warrant did not contain "any express provision" as to the language of the British Military courts or to the language in which the court should be addressed. However, the UNWCC noted that the rules of procedure followed in British war crimes trials are in general those followed in English civil courts. ${ }^{134}$ These two cases suggest that there were some inconsistencies in the way in which courts viewed the right of the accused to comprehend court proceedings.

${ }^{130}$ United States Provisions, Doc. Misc. No. 41 (n 97).

${ }^{131}$ UNWCC, 'The Belsen Trial: The Trial of Josef Kramer and 44 Others, British Military Court, Luneburg, 17 September-17 November 1945' Law Reports of Trials of War Criminals: Selected and Prepared by the United Nations War Crimes Commission (Vol. II) (His Majesty's Stationery Office 1947); Report submitted to the United Nations (n 91) 254.

${ }^{132}$ UNWCC, The Belsen Trial in Luneburg - Remarks by Dr Cyprian, Doc. C.151 (15 October 1945) 4.

${ }^{133}$ UNWCC, 'The Scuttled U-Boats Case: The Trial of Oberleutnant Gerhard Grumpelt, British Military Court held at Hamburg, Germany on 12 and 13 February 1946' Law Reports of Trials of War Criminals: Selected and Prepared by the United Nations War Crimes Commission (Vol. I) (His Majesty's Stationery Office 1947) 65-6; Report submitted to the United Nations (n 91) 255.

134 'The Scuttled U-Boats Case' (n 133) 65-66. 


\subsubsection{Punishment}

Those defendants who were convicted in the national trials were punished in a variety of ways. In reviewing the documents, it was clear that the defendants were sentenced to death (by hanging or by shooting), sentenced to life or shorter-term imprisonment, or instructed to pay a fine. The documents, however, show that the war crimes trials issued inconsistent sentences. For instance, Narayanan noted that there were disproportionate sentences in the British trials of Japanese war criminals in Malaya and Singapore. ${ }^{135}$ The case of Yamashita, where the defendant was sentenced to death before the United States Military Tribunal, has been referred to as "legal lynching". ${ }^{136}$ On the other hand, an Australian Military Court found Takehiko Tazaki guilty of cannibalism and of mutilating the dead and commuted his death sentence to only five years imprisonment with hard labor. ${ }^{137}$

By the spring of 1947, there were calls within the British Parliament and press for the end of war crimes trials and the release of certain German war criminals due to the time that had elapsed since the capitulation of Germany. There were also reports that doubted the level of justice of the war crimes trials and the treatment of detainees held in custody. ${ }^{138}$ For example, thousands of Japanese citizens and Christian organizations called for the release of Japanese war criminals who were viewed as "sacrificial scapegoats for a war that all right-thinking people now deplored". ${ }^{139}$ Following the policy of rapprochement and appeasement with Japan and Germany after the end of World War II, many of those imprisoned received a reduction in sentence and were repatriated to Japan. By the late 1950 s, there were no Japanese war criminals serving sentences that had been imposed by the various war crimes courts in Hong Kong. ${ }^{140}$

135 Narayanan (n 86).

${ }^{136}$ I. Dear and M. R. D. Foot (eds.), The Oxford Companion to the Second World War (Oxford University Press 1996) 544, 1292; P. R. Piccigallo, The Japanese on Trial: Allied War Crimes Operations in the East, 1945-1951 (University of Texas Press 1979) 195.

137 Report submitted to the United Nations (n 91) 122.

${ }^{138}$ History of the UNWCC (n 3) 145.

${ }^{139}$ R. John Pritchard, 'The Gift of Clemency Following British War Crimes Trials in the Far East, 1946-1948' (1996) 7 Criminal Law Forum 15, 24.

${ }^{140}$ Linton (n 87) 40-41. 


\subsubsection{Right to Appeal}

British and Australian Military Courts did not provide for the right of appeal in the "ordinary sense of the word". ${ }^{141}$ However, the accused was allowed $48 \mathrm{~h}$ to give notice of his intent to submit a petition against the sentence and/or finding. The defendant was allowed 14 days to submit the petition to the Confirming Officer who would refer the filing to the Judge Advocate. ${ }^{142}$ Similarly, a convicted person was given 14 days to petition a sentence and/or finding by a United States Military Government Court. The UNWCC noted that although there was no "appeal", as there is in judicial proceedings, the Commanding General had "trained legal advice as to what, in right and justice, should be done" and that no execution occurred unless it was approved and reviewed by a higher military authority. ${ }^{143}$

The French Code de Justice Militarie allowed for appeal within $24 \mathrm{~h}$ of sentencing. However, those sentenced by a Military Tribunal were not able to appeal their sentences or the findings. ${ }^{144}$ In the trial of Robert Wagner and Six Others, the defendants appealed the decision of the court on the basis that they were not provided with the indictment or with certain evidence on time. This plea, however, was rejected. ${ }^{145}$

Under Norwegian law, the prosecution had "an absolute and unlimited right to appeal" for the benefit of the accused. ${ }^{146}$ For instance, in the trial of Hans Paul Helmuth Latza and Two Others before a Norwegian court, an appeal was filed by the Prosecution on behalf of all accused and by Latza on his own behalf. The Supreme Court of Norway quashed the initial sentences imposed by the Lagmannsrett and ordered a re-trial, which acquitted all of those ac-

\footnotetext{
${ }^{141}$ Report submitted to the United Nations (n 91) 256-260.

142 Ibid; Royal Warrant (n 99) Regulation 10; see also M. Carrel, 'Australia's Prosecution of Japanese War Criminals: Stimuli and Constraints' (DPhil thesis, University of Melbourne 2005).

${ }^{143}$ UNWCC, 'United States Law and Practice Concerning Trials of War Criminals by Military Commissions and Military Government Courts' Law Reports of Trials of War Criminals (Vol. I) (n 133) 121; Report submitted to the United Nations (n 91) 257-258.

${ }^{144}$ Report submitted to the United Nations (n 91) 259. The right to appeal was also provided for under Article 15 of the Polish Law of 31 October 1946 and under Article 16 of the Yugoslav War Crimes Law of 25 August 1945.

${ }^{145}$ UNWCC, 'Robert Wagner and Six Others: Permanent Military Tribunal at Strasbourg 23rd April to 3rd May 1946 and Court of Appeal 24 July 1946' Law Reports of Trials of War Criminals: Selected and Prepared by the United Nations War Crimes Commission (Vol. III) (His Majesty's Stationery Office 1947) 23-56.

${ }^{146}$ Law Reports of Trials of War Criminals (Vol. III) (n 145) 90.
} 
cused. ${ }^{147}$ Under Dutch law concerning the trials of war criminals, the accused had the right to appeal in cassation if the defendant was sentenced to death or to more than six years in prison or if the prosecution made an appeal in cassation. ${ }^{148}$

Before the Polish Supreme National Tribunal, which tried persons accused of war crimes, those who were sentenced to death had the right to appeal for mercy to the President of the National Council. Appeals of the judgments of the Supreme National Tribunal were not allowed, as the decisions were final. However, a resumption of the trial was allowed in certain circumstances. ${ }^{149}$

The UNWCC documents have demonstrated that a number of defendants filed petitions and appeals against their findings and sentences. However, further investigation is needed to determine whether those convicted were provided with the opportunity to appeal judgments and sentences and whether their petitions were fairly considered by the higher authorities.

${ }^{147}$ UNWCC, 'Trial of Hans Paul Helmuth Latza and Two Others: Eisivating Lagmannsrett (Court of Appeal) and the Supreme Court of Norway 18th February 1947-3rd December 1948' Law Reports of Trials of War Criminals: Selected and Prepared by the United Nations War Crimes Commission (Vol. XIV) (His Majesty's Stationery Office 1947) 49-50. See also UNWCC, 'Trial of Kriminalassistent KarlsHans Hermann Klinge: Eidsivating Lagmannstratt and Supreme Court of Norway 8th December 1945 and 27 February 1946' Law Reports of Trials of War Criminals (Vol. III) (n 145) 1-15; UNWCC, 'The Trial of Gerhard Friedrich Ernst Flesch, SS OBE Sturmbannführer Oberregierungsrat: Frostating Lagmannsrett (NovemberDecember 1946) and Supreme Court of Norway (February 1948)' Law Reports of Trials of War Criminals: Selected and Prepared by the United Nations War Crimes Commission (Vol. VI) (His Majesty's Stationery Office 1947) 118-120.

${ }^{148}$ UNWCC, Law Reports of Trials of War Criminals: Selected and Prepared by the United Nations War Crimes Commission (Vol. XI) (His Majesty's Stationery Office 1947) 105; UNWCC, 'Trial of Hans Albin Rauter: Netherlands Special Court in 'S-Gravenhage (The Hague) (Judgment delivered on 4th May 1948) and Netherlands Special Court of Cassation (Judgment delivered on 12th January 1949)' Law Reports of Trials of War Criminals: Selected and Prepared by the United Nations War Crimes Commission (Vol. XIV) (His Majesty's Stationery Office 1947) 89; UNWCC, 'Trial of Willy Zuehlke by the Netherlands Special Court in Amsterdam (Judgment delivered on 3rd August 1948) and Netherlands Special Court of Cassation (Judgment delivered on 6th December 1948)' Law Reports of Trials of War Criminals (Vol. $X I V)$ (n 148) 139.

${ }^{149}$ UNWCC, Law Reports of Trials of War Criminals: Selected and Prepared by the United Nations War Crimes Commission (Vol. VII) (His Majesty's Stationery Office 1947) 95-97. 


\section{CONCLUSION}

The UNWCC was seen as an arbitrator and as an advisor for the States who sought to hold war criminals accountable. The UNWCC delegates also acted as observers as they attended various trials, such as the Peleus trial, the Belsen trial, the Dachau trial and the Mauthausen trial. ${ }^{150}$ For instance, Lord Wright, Chairman of the UNWCC stated that, during the Belsen trial, he "occupied the seat marked for the British observer and could observe and admire the fairness of the trial, though [he] noted, as in other such cases, that fairness was not generally compatible with expedition". ${ }^{151}$ However, given that Lord Wright later stated that "all the accused were entitled to was a fair trial and that they got"152 and that only $21 \%$ of persons were acquitted, begs the question of whether the UNWCC acted as an arbitrator in relation to fair trial rights.

I would argue that the UNWCC was responsible for advising Allied governments on matters of a technical nature. This included the type of tribunals to be employed for trying war criminals, the relevant substantive and procedural laws to be adopted, and the rules of evidence to be followed. ${ }^{153}$ Therefore, the Commission should have been responsible for securing the rights of the accused in all aspects of the war crimes trials. Following a review of nearly 600

${ }^{150}$ UNWCC, Minutes of Eighty-second Meeting, Doc. M.82 (24 October 1945) 10; UNWCC, Minutes of Eighty-seventh Meeting, Doc. M.87 (28 November 1945) 2; UNWCC, Minutes of Hundredth and second Meeting, Doc. M.102 (3 April 1946) 3-4. See UNWCC, 'The Peleus Trial: Trial of Kapitanleutnant Heinz Eck and Four Others for the Killing of Members of the Crews of the Greek Steamship Peleus, Sunk on the High Seas British Military Court for the Trial of War Criminals Held at the War Crimes Court, Hamburg, 17-20 October 1945' Law Reports of Trials of War Criminals (Vol. I) (n 133); 'The Belsen Trial' (n 131); UNWCC, 'The Dachau Concentration Camp Trial: Trial of Martin Gottfried Weiss and Thirty-Nine Others, General Military Government Court of the United States Zone, Dachau, 15 November-13 December 1945' Law Reports of Trials of War Criminals (Vol. XI) (n 148); UNWCC; 'The Mauthausen Concentration Camp case, General Military Government Court of the United States Zone Dachau 29 March-13 May 1946' (as cited in Law Reports of Trials of War Criminals (Vol. XI) (n 148) 15); UNWCC, Notes on Visits to Trials at Nuremberg and Dachau(26 March-3 April 1946), Doc. C.189 (12 April 1946).

${ }^{151}$ Law Reports of Trials of War Criminals (Vol. II) (n 131) ix; 'The Belsen Trial' (n 131).

${ }^{152}$ Law Reports of Trials of War Criminals (Vol. XV) (n 75) xi.

${ }^{153}$ UNWCC, Article on the United Nations War Crimes Commission in 'The International Law Quarterly, Doc. Misc. No. 97 (13 June 1947) 2. 
documents, I was unable to locate detailed information on the number of trials where the UNWCC delegates attended.

It is evident, however, that national trials did provide for various fair trial protections that are present in current international human rights instruments. This finding is consistent with the position taken by the UNWCC. The UNWCC argued that the "basic elements of a fair trial" for the accused were regularly stressed by the domestic systems. ${ }^{154}$ In a report submitted to the United Nations Economic and Social Council, the UNWCC provided a detailed study of human rights, including a survey of the rights of the accused, in the trials of war criminals. The Commission recorded the characteristics of a fair trial before the national courts and noted the attempts of the national courts ${ }^{155}$ to provide fair trial rights for the accused. In relation to the trials held by the Allied nations, the UNWCC reported that:

The rules relating to evidence and procedure which are applied in trials by courts of the various countries ... when viewed as a whole, are seen to represent an attempt to secure to the accused his right to a fair trial while ensuring that the guilty shall not escape punishment because of legal technicalities. ${ }^{156}$

It is interesting to note that Lieutenant General Ito Takeo, who was sentenced to 12 years imprisonment, stated that he originally worried about the procedure of the court but "began to feel more at ease with the President and the members of the Court because of the way the trial has been conducted". ${ }^{157}$ The defense counsel in the Gozawa Sadaichi trial also expressed that the court had conducted the trial with "scrupulous fairness and impartiality". ${ }^{158}$ Linton argues that the British Military courts in Hong Kong were not "kangaroo courts" and that courts offered a "broadly fair trial in difficult circumstances". 159

${ }^{154}$ Law Reports of Trials of War Criminals (Vol. III) (n 145) 189.

${ }^{155}$ Law Reports of Trials of War Criminals (Vol. III) (n 145) 189; See UNWCC, 'The Justice Trial: Trial of Josef Alstötter and Others, United States Military Tribunal, Nuremberg, 17 February-4 December 1947' Law Reports of Trials of War Criminals (Vol. VI) (n 147); 'The Belsen Trial' (n 131); 'The Hostages Trial' (n 85).

${ }^{156}$ Law Reports of Trials of War Criminals (Vol. XV) (n 75) 190, 273.

${ }^{157}$ Post Sentence Statement of the accused in Trial of Sergeant Major Ito Junichi, British Military Court in Hong Kong, Case No. WO235/1107 Transcript 214, Slide 247 (as cited in Linton (n 87) 62).

158 C. Sleeman (ed.) Trial of Gozawa Sadachi and Nine Others (London, William Hodge \& Co. 1948) 205; Piccigallo (n 136) 106.

${ }^{159}$ Linton (n 87) 61. 
However, given that there are still hundreds of documents that need to be reviewed, and that some documents remain unavailable for inspection, future scholars should accelerate their efforts to review the documents and examine the rights of the accused in greater detail. Regardless of the extraordinary efforts of the UNWCC to bring to justice those who committed heinous crimes during the War, its success can only be affirmed if the trial proceedings were fair to the accused. In light of the fact that various commentators have challenged the fairness of the minor war crimes trials, further examination of the documents released, and those that remain classified, will shed light on the fairness of the trials as a whole.

Notwithstanding the final judgment on the fairness of these trials, there can be no doubt that the UNWCC played a significant role in the development of international criminal law. The debates among the delegates on the primary jurisdiction of the national courts and the creation of an international court mirror the debates that would occur years later during the creation of the ICC. The principle of complementarity, which is the cornerstone of the Rome Statute, undeniably has its roots in the mission and aspirational goals of the UNWCC.

\section{OPEN ACCESS}

This article is distributed under the terms of the Creative Commons Attribution License which permits any use, distribution, and reproduction in any medium, provided the original author(s) and the source are credited. 